\section{Digital Agenda, New Technologies and Education for the Integration of Europe: an Economic Study}

\section{Javier Cifuentes-Faura}

University of Murcia

$\Gamma$ crossef

http://dx.doi.org/10.5755/j01.eis.1.15.28296
EIS 15/2021

Digital Agenda, New Technologies and Education for the Integration of Europe: an Economic Study

Submitted 03/2021

Accepted for publication 06/2021

Abstract

and interact with people everywhere. The European Commission established the Digital Agenda for Europe with the aim of improving the speed of navigation, establishing a single market for telecommunications and achieving a digital single market. We highlight the importance of applying new technologies in the field of education, since teaching and learning through these means will contribute to increasing creativity and reasoning capacity, allowing for more interactive and participative learning. The Horizon Report and the new emerging technologies proposed by that report are analysed, and are aimed not only at facilitating learning, but also at enabling a more integrated Europe. It also presents some technological ideas to be developed in the educational field that will enhance the development and integration of the EU Member States. Furthermore, in order to analyse the influence of the use of the Internet and new technologies on other socio-economic variables, a regression analysis has been carried out. The objective is to study whether in any way the fact that citizens use the Internet affects variables such as Gross Domestic Product, unemployment or Human Development Index which may affect the integration of Europe.

KEYWORDS: Europe, integration, new technologies, education, socio-economic variables.

The development of new technologies is a key element for globalisation in Europe. They are essential for competitiveness in an increasingly digitalised world economy. Therefore, more than 20 billion Euros from the European Regional Development Fund (ERDF) and the Cohesion Fund are available for investments in the field of Information and Communication Technologies (ICT) during the 2014-2020 funding period (Nigohosyan and Vutsova, 2018). These investments are aimed at creating a single digital market, where all people can interact globally.

The specific objective of ICT research and innovation is to enable Europe to support, develop and exploit the opportunities offered by the progress of new technologies for the benefit of its citizens, businesses and scientific communities. To ensure a secure, open and fair digital environment, the European Commission has developed the Strategy for the Digital Single Market (Frosio, 2017; Lucian, 2018), which is structured around three pillars: improving access of consumers and businesses to digital goods and services in Europe, creating the right conditions for the success of digital services and networks, and realising the full growth potential of the digital economy.

The European Commission measures through the Digital Economy and Society Index (DESI) (Russo, 2020) the progress of the different European Union countries towards a digital society and economy, providing information on the digital performance and competitiveness of European countries.

\section{Introduction}

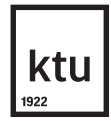

European Integration Studies No. 15 / 2021, pp. 55-62 doi.org/10.5755/j01.eis.1.15.28296 


\section{Digital}

\section{Technologies}

\section{Table 1}

Students' self-assessment in recognizing false information

Source: own elaboration

Figure 1

Countries with advanced digital economies in the EU in 2019

Source: DESI 2019,

European Commission
For this reason, this paper reviews the DESI Report and the Horizon Report to analyse their latest advances and evidence, and it provides a regression analysis to study whether in any way the fact that citizens use the Internet and new technologies affects some variables socio-economics.

The DESI report is structured around 5 dimensions (Table 1), the first two contributing 25\% each to the overall value of the index. The integration of digital technology represents $20 \%$, the use of internet services by citizens and the dimensions of digital public services each contribute $15 \%$.

\begin{tabular}{c|l|l}
\hline & \multicolumn{1}{|c|}{ Dimensions } & \multicolumn{1}{c}{ Meaning } \\
\hline 1 & Connectivity & $\begin{array}{l}\text { Fixed broadband, mobile broadband, fast and ultrafast } \\
\text { broadband and prices }\end{array}$ \\
\hline 2 & Human capital & Internet user skills and advanced skills \\
\hline 3 & Use of Internet & Citizens' use of internet services and online transactions \\
\hline 4 & Integration of digital technology & Business digitisation and e-commerce \\
\hline 5 & Digital public services & e-Government and e-health \\
\hline
\end{tabular}

Figure 1 shows the countries with the most advanced digital economy by 2019, i.e., with the highest digital performance. Finland, Sweden, the Netherlands and Denmark and the United Kingdom are the countries with the most advanced digital economy. On the other hand, Bulgaria and Romania occupy the last positions in this ranking. These countries are among those with a lower per capita GDP (GDPpc), and can be associated, among other things, that having a lower GDPpc influences the level of digitalization of the country.

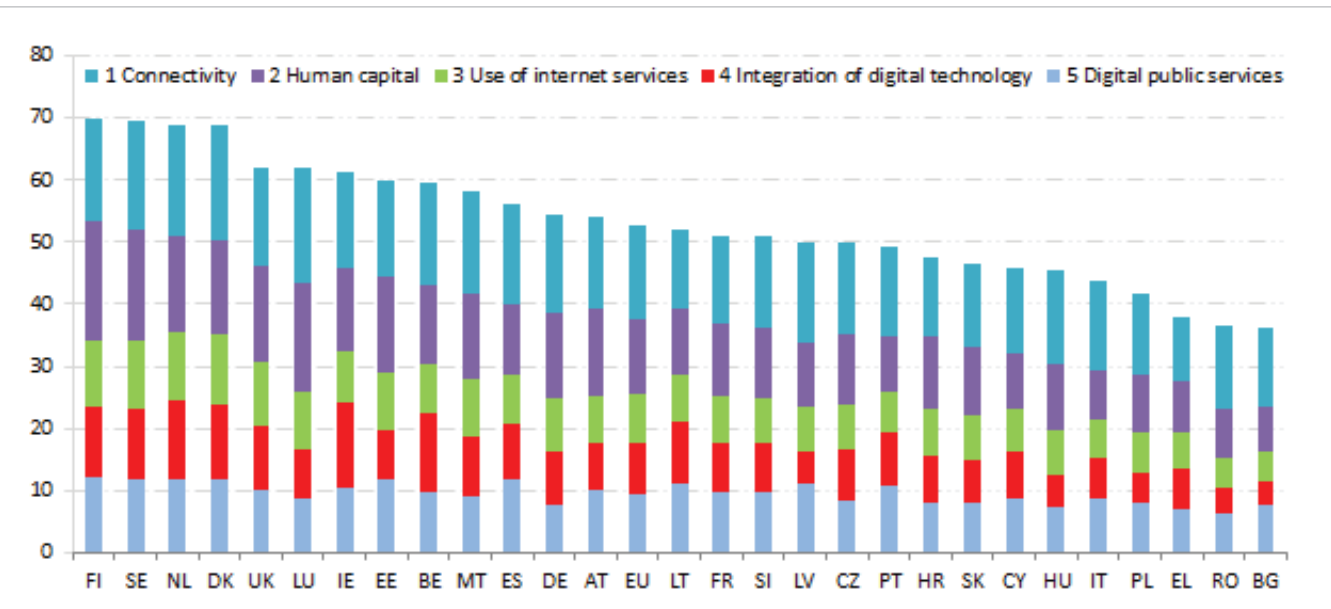

Europe must work to reduce this technological gap between countries, encouraging investment in very high capacity networks to meet the growing connectivity needs of Europeans.

Currently, the progress of countries is based on increasing the knowledge of their citizens, which is a challenge in the field of education, since it requires the incorporation of ICTs. Education drives growth, innovation and job creation. This is why it is so important for Europe to invest in digital skills on a continuous basis in order to achieve greater development and integration among its Member States. 
It is undoubtedly very important that new technologies should advance and that Europe should take steps to implement them among its citizens. It is also essential, however, that they are introduced in the field of education, an area fundamental to Europe's development.

Since 2004, and on an annual basis, the Horizon Report has been published, showing the trends, challenges and technological developments that will have an impact on teaching and learning (Jonhson et al., 2012; Adams Becker et al., 2017). The 2019 report (Alexander et al., 2019) forecasts 6 technologies that will be implemented in the short, medium and long term in educational institutions (Table 2).

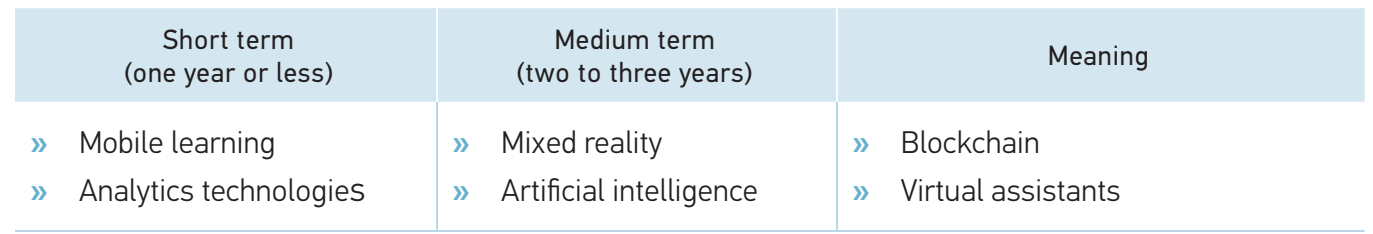

Both mobile learning and analytical technologies are already implemented in many education systems. Among their advantages, the total accessibility and interaction of the contents, the connectivity and the access at any time and place stand out. Augmented, virtual and mixed reality have enabled mobile learning to become more active and collaborative. Lai and Hwang (2014) highlight the ease of consulting the necessary information in real time through mobile devices. Berns et al. (2017) and Martín-Ramos et al. (2017) relate the use of mobile devices to classroom teaching and pedagogical evaluation using various techniques: simulations in the case of the former and the collaborative agenda on the part of the latter.

In the context of big data and artificial intelligence arises the use of analytical technologies in everyday life. With them, all existing data can be interpreted to improve institutions and the experiences of students and teachers (Reyes Dixson and Nuñez Maturel, 2015; André et al., 2017; Malik, 2019). Some institutions have already implemented Business Intelligence systems (Cobo et al., 2016) and are using it, for example, to help students who need support, customize content, reduce workloads and produce educational applications.

Mixed reality (combination of virtual reality and augmented reality) allows the creation of new spaces in which both objects and real or virtual people interact so that students can access simulations that help them to better approach real situations within their learning process and experience them first-hand. Many studies focus on the progress this method is making (Lindgren et al., 2016; Birt et al., 2017; Chen and Duh, 2018).

The advances that will take the longest to apply to the educational system are Blockchain technology and virtual assistants. The first of these began to be applied in the financial world and now the education sector is studying how to adopt it for use in transactions such as smart contracts or identity verification. The works of Grech and Camilleri (2017) and Chen et al. (2018) show us some of its applications such as improving the security of grades, academic records, minutes ..., and the student can have his academic certificate anywhere or anytime.

Virtual assistants are used to answer user questions. Students can use them, for example, to measure study time and become more efficient. One strategy for improving interactivity is to use virtual teaching assistants to augment and amplify interaction with human teachers (Goel and Polepeddi, 2016). A virtual reality assistant based enhanced technology for learning primary geography is proposed by LV and Li (2015).

\section{Horizon Report}

Table 2

Emerging technologies predicted by the 2019 Horizon Report. 
Through any of the technologies discussed, students will be able to engage in more active and dynamic learning, and it will serve them in many aspects of their lives. It will not only enable the student to better develop his or her skills, but it will also enable him or her to have more knowledge in the future. Thus, through mobile learning students can quickly access content and information, learn more about other cultures or communicate with other students and people anywhere in the world. By enhancing this learning in the classroom we can have a more cohesive Europe where the use of technologies is promoted. That is why budgets should be allocated to buy tablets and mobile devices for the classroom so that students can develop their technological skills. However, not only must we invest in the purchase of technological materials, but also in ensuring adequate Internet speed that allows immediate and effective communication.

Other actions in which Europe must invest are the creation of online platforms for self-learning (artificial intelligence), with the aim of optimising training and improving student participation. This would increase completion rates. Some platforms already use artificial intelligence to examine data and find patterns to help identify which lessons are effective and which need to be improved. An answer correction system could be put in place to enhance errors in the following questions so that the parts where the student fails are further reinforced. In this way, the user is not only evaluated by his or her successes, but also learns from his or her own mistakes. These tools could, for example, contribute to improve the learning of a language, favouring a greater cohesion among European citizens, by knowing a greater number of languages.

On the other hand, it would be a good idea to invest in educational robotics, so that robots act as tutors in virtual courses. This digital learning will provide students with a more complete learning experience, and they will be able to obtain help more easily. They could access knowledge when they need it, by having the opportunity to ask questions in natural language as they would with another student or a teacher. In this way, if the implementation of intelligent tutors is promoted, it will be possible to optimize the search and use of content among an immense amount of available resources.

A regression analysis is set out in the following sections to highlight the importance of new technologies and the use of Internet in Europe.

\section{Methodology}

Education and new technologies are key to European integration. For this reason, in this work we wanted to verify the importance that ICT and the Internet are having in Europe. From the data obtained from Eurostat, we have obtained the percentage of individuals who use the Internet during the year on some occasion. Two periods have been compared, 2009, during the economic crisis, and 2018, the recovery period. Furthermore, in order to analyse the influence of the use of the Internet and new technologies on other socio-economic variables, a regression analysis has been carried out. The objective is to study whether in any way the fact that citizens use the Internet affects variables such as Gross Domestic Product (GDP), unemployment or Human Development Index $(\mathrm{HDI})$. It is assumed that the countries whose citizens use the Internet most have also received more education in its use.

All countries have significantly increased the number of users using the Internet through new technologies (Figure 2). Luxembourg tops the list of European countries whose population is using the Internet most in 2018, with 97 per cent of the population having used it at some time during that year, compared to 87 per cent in 2009. It is followed by the United Kingdom, the Netherlands and Finland with $95 \%$ of the population. These countries also tend to be the most advanced in education, generally performing well in the PISA report produced by the OECD, especially Finland, which stands out for having one of the best education systems (Simola, 2005; Kupiainen et al., 2009; Rautalin, 2018). If we compare 2009 with 2018, Romania (+52\%) and Cyprus (+42\%) have experienced the greatest variation in the increase of individuals using the internet in this period. Investment in 


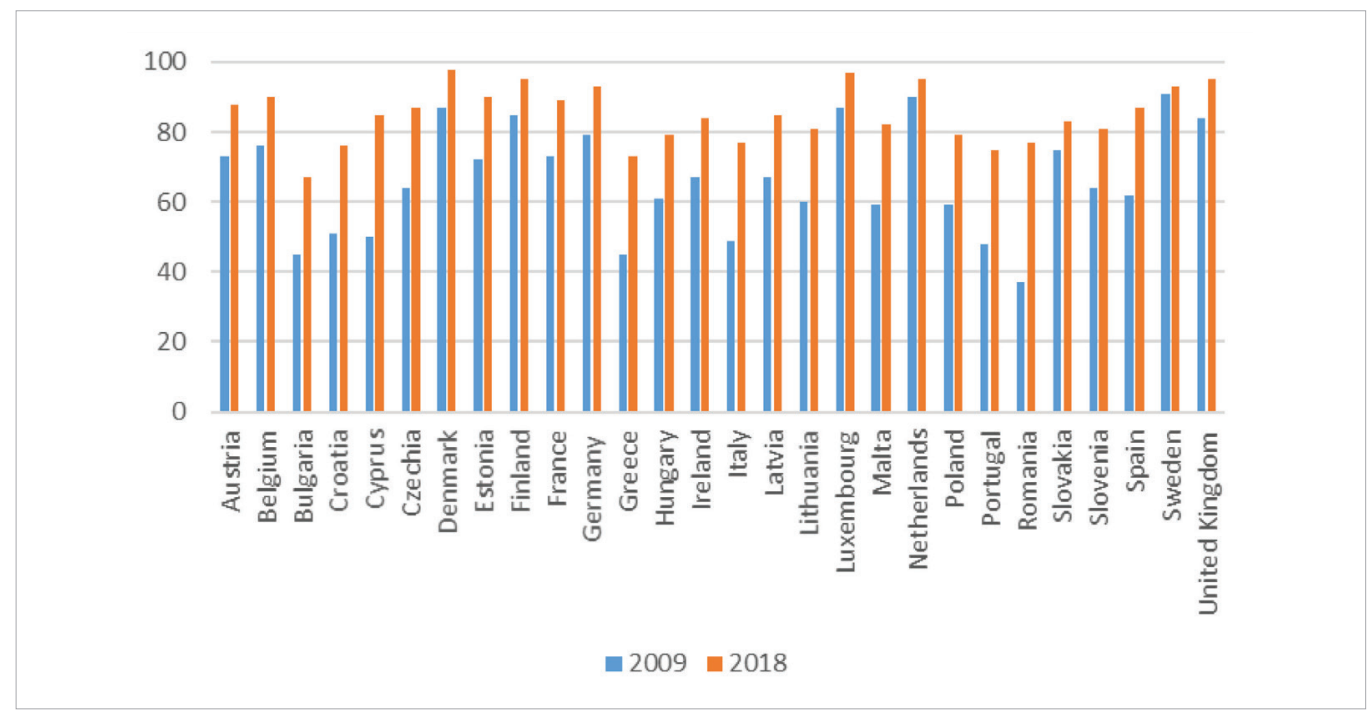

Figure 2

Percentage of individuals who have used the Internet during the year 2009 and 2018.

Source: own elaboration based on Eurostat database.

new technologies and education, and greater connection through the Internet can be very satisfactory for the development of future generations and for the integration of Europe.

Table 3 shows the bivariate correlations between the different variables in 2009 and 2018. There is a strong direct correlation in both years between the new technologies (measured as the percentage of interacting citizens who use the Internet at some time each year) and the logarithm of GDP. These data reveal that the countries with the greatest economic development are those that use the Internet the most. This may be due to the fact that a greater allocation of economic resources may make it possible to invest more in the purchase of technologies and in teaching them.

\begin{tabular}{l|c|c|c|c|c}
\hline & & ICT & log GDP & Unemployment & HDI \\
\hline \multirow{2}{*}{ ICT } & 2009 & 1 & 0.662 & -0.130 & 0.282 \\
\hline \multirow{2}{*}{ log GDP } & 2018 & 1 & 0.794 & -0.354 & -0.094 \\
\hline \multirow{2}{*}{ Unemployment } & 2009 & 0.662 & 1 & -0.120 & 0.301 \\
\hline \multirow{2}{*}{$*$} & 2018 & 0.794 & 1 & -0.168 & -0.042 \\
\hline \multirow{2}{*}{ HDI } & 2009 & -0.130 & -0.120 & 1 & 0.042 \\
\hline
\end{tabular}

Table 3

Correlation matrix

In order to analyse the influence of the use of the Internet and new technologies on other variables related to the specific socio-economic context of each country (lonescu, 2013; Chen and Neshkova, 2020), a regression analysis has been carried out. The dependent variable is the percentage of citizens using the Internet. The independent variables are the logarithm of GDP per capita, the unemployment rate and the HDI. The GDP aims to measure the country's economic growth (Angelache, and Sacla, 2016), while the HDI measures human development through other indicators such as life expectancy, educational attainment and income (Eren et al., 2014). The HDI data are taken from the Human Development Report published worldwide by the United Nations Development Programme (UNDP) and the GDP and unemployment data from the Eurostat database. 
Table 4

Coefficients of the regression model

\section{Conclusion}

\begin{tabular}{|c|c|c|c|c|}
\hline & \multicolumn{2}{|c|}{2009} & \multicolumn{2}{|c|}{2018} \\
\hline & $\begin{array}{l}\text { Unstandardized } \\
\text { Coefficients }\end{array}$ & $\begin{array}{l}\text { Standardized } \\
\text { Coefficients }\end{array}$ & $\begin{array}{l}\text { Unstandardized } \\
\text { Coefficients }\end{array}$ & $\begin{array}{c}\text { Standardized } \\
\text { Coefficients }\end{array}$ \\
\hline (Constant) & $\begin{array}{c}-79.847^{\star *} \\
(35.191)\end{array}$ & & $\begin{array}{l}-13.478 \\
(16.392)\end{array}$ & \\
\hline $\log (G D P)$ & $\begin{array}{c}32.749^{\star *} \\
(8.395)\end{array}$ & 0.626 & $\begin{array}{c}23.130^{\star *} \\
(3.582)\end{array}$ & 0.755 \\
\hline Unemployment & $\begin{array}{l}-0.225 \\
(0.588)\end{array}$ & -0.058 & $\begin{array}{l}-0.442^{*} \\
(0.234)\end{array}$ & -0.223 \\
\hline HDI & $\begin{array}{c}9.645 \\
(15.974)\end{array}$ & 0.096 & $\begin{array}{l}-1.025 \\
(3.667)\end{array}$ & -0.033 \\
\hline $\mathrm{R} 2$ & 0.670 & & 0.825 & \\
\hline R2 Adjusted & 0.449 & & 0.681 & \\
\hline
\end{tabular}

Standard error in parentheses

${ }^{* *} p$-value $<0.05,{ }^{*} p p$-value $<0.1$

The data in Table 4 show that, in the two years studied, the regression model has a high explanatory power, especially in 2018 (see adjusted $\mathrm{R}^{2}$, which indicates what percentage of the variation in the dependent variable is explained jointly by all the independent variables and varies between 0 and 1 , the closer to 1 the model's adjustment to the variable to be explained).

Standardised regression coefficients allow the relative importance of each independent variable within the equation to be assessed. In general, a variable is more important the higher (in absolute value) its normalized coefficient is. The variable with the highest weight in 2009 and 2018 is the one related to GDP.

It would be very positive to encourage collaborative learning through new technologies, since it will be possible to make groups of like-minded people to carry out tasks together, increasing the effectiveness of learning. These groups could be interconnected all over the world.

It has become clear that there are many benefits associated with digital education and that its practice is, and will be, even more essential. Europe must therefore ensure that all citizens have access to the internet and the necessary digital skills, working to develop quality education. We are at the beginning of the fourth industrial revolution and the digitisation of EU countries to be able to compete in the era of the data economy and artificial intelligence are issues that must be on the Union's agenda. It is essential for Europe to invest in technologies for education, as this is a key aspect of promoting integration between countries. Relations between Member States and citizens would be strengthened.

However, at present, there are still countries that do not have the same opportunities in terms of technologies because they do not have the necessary financial resources. The European Union must try to alleviate these problems, since the new technologies are bringing those who use them closer together, but excluding those who do not. Therefore, education policies have a lot to say in terms of preventing or, at least, compensating for these inequalities in access to information and knowledge. Within the education system, it will be necessary to articulate measures that benefit the learning and use of new technologies for less advantaged groups. In this process, teachers should be provided with the appropriate tools and training to use ICT at all levels of education, promoting more inclusive and personalised education and training systems.

Europe must create a dynamic digital single market to access the benefits of the digital age. The 
governance and transparency of collective rights management must be improved and adapted to technological progress. The challenge is great, but the benefits will be even greater, leading to a truly equitable, fair and inclusive society.

It was important to raise awareness of the need to learn new technological methods. This acquired knowledge can be put into practice during your working and personal life, contributing to a greater connection between all regions. The new technologies are an incredible advance in society and Europe must continue to promote and propose measures such as those described for the implementation of these technologies in all areas.

Therefore, we wanted to check, through a regression analysis, the influence of the use of the Internet and new technologies on other socio-economic variables.

It has been realized that the most economically developed countries are those that use the Internet the most. This may be due to the fact that a greater allocation of economic resources may allow more investment in the purchase of technologies and their teaching.

Adams Becker, S., Cummins, M., Davis, A., Freeman, A., Hall Giesinger, C., \& Ananthanarayanan, V. (2017). NMC Horizon Report: 2017 Higher Education Edition. Austin, Texas: The New Media Consortium.

Alexander, B., Ashford-Rowe, K., Barajas-Murphy, N.; Dobbin, G.; Knott, J., McCormack, M.; Pomerantz, J., Seilhamer, R., Weber, N. (2019). EDUCAUSE Horizon Report: 2019 Higher Education Edition; EDUCAUSE: Louisville, CO, USA.

André, E., Baker, R., Hu, X., Rodrigo, M. T., \& du Boulay, B. (2017). Artificial Intelligence in Education. Gewerbestrasse: Springer. https://doi.org/10.1007/978-3319-61425-0

Angelache, C. D. \& Sacla, C. (2016). Multiple linear regression used to analyse the correlation between GDP and some variables Romanian statistical review-supplement nr.9/2016. p.94-99.

Berns, A., Palomo-Duarte, M., Isla-Montes, J. L., Dodero, J. M., \& Torre, P. (2017). Agenda colaborativa para el aprendizaje de idiomas: del papel al dispositivo móvil. RIED. Revista Iberoamericana de Educación a Distancia, 20(2). https://doi.org/10.5944/ ried.20.2.17713

Birt, J., Moore, E., \& Cowling M.A. (2017). Piloting Mobile Mixed Reality Simulation in Paramedic Distance Education. In 2017 IEEE 5th International Conference on Serious Game and Applications for Health (SeGAH), Perth, Australia. https://doi.org/10.1109/SeGAH.2017.7939270

Chen, G., Xu, B., Lu, M. \& Chen, N.-S. (2018). "Exploring blockchain technology and its potential applications for education," Smart Learning Environments, vol. 5, no. 1, p. 1. https://doi.org/10.1186/s40561-017-0050-x

Chen, S. C., \& Duh, H. (2018). Mixed reality in education: recent developments and future trends. In 2018 IEEE $18^{\text {th }}$ International Conference on Advanced Learn- ing Technologies, 367-371. https://doi.org/10.1109/ ICALT.2018.00092

Chen, Y. C., Hu, L. T., Tseng, K. C., Juang, W. J, \& Chang, C. K. (2019). Cross-boundary e-government systems: Determinants of performance. Government Information Quarterly, 36, 449-459. https://doi.org/10.1016/j. giq.2019.02.001

Cobo, H., Gurmendi, L. \& Menéndez, M. (2016). Business Intelligence en el Sistema Universitario Nacional. Sexta Conferencia de Directores de Tecnología de Información, TICAL 2016.

Eren, M., Çelik, A.K., \& Kubat, A. (2014). Determinantf of the Level of Development Based on the Human Development Index: A Comparison of Regression Models for Limited Dependent Variables. Review of European Studies. Vol. 6 (1): 10-23. https://doi. org/10.5539/res.v6n1p10

Frosio, G.F. (2017). Reforming intermediary liability in the platform economy: a European digital single market strategy. Northwest Univ Law Rev Online, 111. Available from https://heinonline.org/ HOL/LandingPage?handle=hein.journals/nulro112\&div=3\&id=\&page $=$ https://doi.org/10.2139/ ssrn.3009155

Goel, A. K., \& Polepeddi, L. (2016). Jill Watson: A Virtual Teaching Assistant for Online Education. Georgia Institute of Technology.

Grech A, \& Camilleri A.F. (2017). Blockchain in Education. Joint Research Centre (Seville site).

Ionescu, L. (2013). The Positive Effect of ICT Infrastructure in Reducing Corruption and Increasing Transparency. Economics, Management, and Financial Markets, 8 (2), 167-172.

Johnson, L., Adams, S., \& Cummins, M. (2012). The NMC horizon report: 2012 higher education edition. Austin, TX: New Media Consortium.

\section{References}


Kupiainen, S., Hautamäki, J., \& Karjalainen, T. (2009). The Finnish education system and PISA. (Ministry of Education Publications, No. 46). Finland: Ministry of Education. Retrieved from http://www.pisa2006.helsinki. fi/files/The_Finnish_education_system_and_PISA.pdf Lai, C.-L., \& Hwang, G.-J. (2014). Effects of mobile learning time on students' conception of collaboration, communication, complex problem- solving, meta-cognitive awareness and creativity. International Journal of Mobile Learning and Organisation, 8(3-4), 276- 291. https://doi.org/10.1504/IJML0.2014.067029

Lindgren, R., Tscholl, M., Wang, S., \& Johnson, E. (2016). Enhancing learning and engagement through embodied interaction within a mixed reality simulation. Computers \& Education, 95, 174-187. https://doi. org/10.1016/j.compedu.2016.01.001

Lucian P. (2018). A few considerations regarding the strategy for the Digital Single Market, Revista Economica, vol. 70, iss. 2, pp. 68-75.

Lv Z, \& LiX. (2015). Virtual reality assistant technology for learning primary geography. In International Conference on Web-Based Learning. Springer International Publishing. 31-40. https://doi.org/10.1007/9783-319-32865-2_4

Malik, G., Tayal, D.K. \& Vij, S. (2019). An Analysis of the Role of Artificial Intelligence in Education and Teaching. In Recent Findings in Intelligent Computing Techniques, Springer, Singapore (pp.407-417). https://doi. org/10.1007/978-981-10-8639-7_42

Martín-Ramos, P., Ramos Silva, M., \& Pereira da Silva, P. S. (2017). Smartphones in the teaching of Physics
Laws: Projectile motion. RIED. Revista Iberoamericana de Educación a Distancia, 20(2). https://doi. org/10.5944/ried.20.2.17663

Nigohosyan, D., Vutsova, A (2018). The 2014-2020 European regional development fund indicators: the incomplete evolution. Social Indicators Research. 137(2), 559-577 https://doi.org/10.1007/s11205017-1610-8

Rautalin, M. (2018). PISA and the criticism of Finnish education: justifications used in the national media debate. Studies in Higher Education, 43(10), 1778 1791. Doi: https://doi.org/10.1080/03075079.2018.1 526773

Reyes Dixson, Y., \& Nuñez Maturel, L. (2015). La inteligencia de negocio como apoyo a la toma de decisiones en el ámbito académico. Revista Internacional de Gestión del Conocimiento y la Tecnología, p.63-73.

Roll, I., \& Wylie, R. (2016). Evolution and Revolution in Artificial Intelligence in Education. International Journal of Artificial Intelligence in Education, 26(2), 582599. https://doi.org/10.1007/s40593-016-0110-3

Russo, V. (2020). "Digital Economy and Society Index (DESI)", European Guidelines and Empirical Applications on the Territory, Studies in Systems, Decision and Control, vol. 208, pp. 427-442. https://doi. org/10.1007/978-3-030-18593-0_31

Simola, H. (2005) The Finnish miracle of PISA: historical and sociological remarks on teaching and teacher education, Comparative Education, 41(4), 455-470. https://doi.org/10.1080/03050060500317810

\section{CIFUENTES-FAURA JAVIER}

\section{Predoctoral researcher}

University of Murcia, Spain

\section{Fields of interests}

Public economy, transparency, public policies

\section{Address}

Faculty of Economics and Business $+34868883898$

javier.cifuentes@um.es 